\title{
Farm adaptation at the rural-urban interface
}

\author{
Shoshanah M. Inwood ${ }^{\text {a* }}$ and Jill K. Clark ${ }^{\mathrm{b}}$
}

Submitted May 22, 2013 / Revised August 2 and September 13, 2013 / Accepted September 13, 2013 /

Published online December 11, 2013

Citation: Inwood, S. M., \& Clark, J. K. (2013). Farm adaptation at the rural-urban interface. Journal of Agriculture, Food Systems, and Community Development, 4(1), 61-78. http://dx.doi.org/10.5304/jafscd.2013.041.007

Copyright (C) 2013 by New Leaf Associates, Inc.

\begin{abstract}
Despite population growth and development at the rural-urban interface (RUI), agriculture continues to persist there. This resilience is partially a reflection of land use policies and market support programs designed to protect farm and ranch land that is vulnerable to nonfarm development. Studies examining the RUI primarily focus on the diversity of production and markets and do not discuss the diversity of operators. As the farmland protection and food systems movements continue to refine policy objectives and decide how to allocate scarce resources, it is critical to have up-to-date statistics on the health and vitality of agriculture at the RUI. Using the 2007 Census of Agriculture statistics, we examine (1) the spatial distribution by county of high-value production and marketing practices assumed to play a role in the persistence and vitality of agriculture at the RUI; and (2) the demographic characteristics of farmers in these

\footnotetext{
a * Corresponding author: Shoshanah M. Inwood, Department of Community Development and Applied Economics, 208H Morrill Hall, The University of Vermont, Burlington, Vermont 05401 USA; +1-802-656-0257; $\underline{\text { Shoshanah.Inwood@uvm.edu }}$

b John Glenn School of Public Affairs, Ohio State University, Columbus, Ohio; +1-614-688-5984; Clark.1099@osu.edu
}

counties. We find that only some types of highvalue production and marketing systems are more prevalent in metropolitan regions, including horses, nursery-greenhouse, and direct sales, while organic production, recreation sales, CSA farms, and valueadded farms are more likely to be concentrated in nonmetropolitan counties. We also find that farmers at the RUI are extremely diverse and that a substantial number of beginning and women farmers are found in nonmetropolitan counties, along with a small but notable number of African American, Hispanic and Native American farmers.

\section{Keywords}

Census of Agriculture, farm adaptation, farmer diversity, metro counties, rural-urban interface

\section{Introduction}

The rural-urban interface (RUI) is the relatively rural space on the edge of urbanized areas (Audirac, 1999); farms and ranches in these geographic areas are highly vulnerable to nonfarm development, yet they continue to thrive and significantly contribute to the U.S. agricultural economy. While RUI counties only represent 20 percent of all U.S. counties, they account for roughly 40 percent of total U.S. agricultural 
production (Jackson-Smith \& Sharp, 2008), ${ }^{1}$ and produce the majority of the nation's fruits, vegetables, and nursery and greenhouse crops (American Farmland Trust [AFT], 2013; JacksonSmith \& Sharp, 2008). Since the 1970s the RUI has often been the focus of local, state and national debates over disappearing farmland, a shrinking farm population, land use policy, and local and regional food systems.

Starting in the 1970s, the U.S. Department of Agriculture's Economic Research Service (ERS) published a series of reports and research studies documenting the complexity of agriculture at the RUI and the significant contributions metro farmers make to U.S. agricultural production. These research papers and reports examined farm size and type and ownership patterns, and aimed to understand the ways in which metro farmers have been able to persist and adapt to nonfarm development pressures (Heimlich \& Brooks, 1989; Heimlich \& Anderson, 2001). Recognizing the importance and vulnerability of RUI agriculture, farm advocacy organizations, researchers, and policy-makers used these reports to develop a variety of land-based and market-based strategies designed to support farmers at the RUI (AFT, 1997; Bryant \& Johnston, 1992). Today, farmland preservation and efforts to promote local and regional food systems as a viable economic livelihood for farmers (e.g., through on-farm valueadded strategies, promoting higher intensity production, etc.) have become mainstream; these efforts are no longer limited to community- or state-level campaigns but are now a part of federal farm policy (AFT, 2013; Clancy \& Ruff, 2010; Lyson, 2004; Oberholtzer, Clancy, \& Esseks, 2012).

As the farmland protection and food systems movements continue to refine policy objectives and decide how to allocate scarce resources, it is

\footnotetext{
${ }^{1}$ Sharp and Jackson-Smith (2008) represent RUI counties as "counties with Urban Influence Codes (UIC) 1 through 4 (or 1,267 counties total), as well the a small number of counties in UIC categories 5-7 that experienced population growth above the national average of 13.15 percent between 1990-2000 (255 counties fall into this category). UIC codes are developed by the USDA-ERS and can be accessed online at http://www. ers.usda.gov/Briefing/Rurality/urbaninf/" (p. 10).
}

critical that they have the latest statistics on the health and vitality of RUI agriculture. While there have been recent reports examining more macrolevel statistics that assess the overall production levels of RUI agriculture (Esseks, Oberholtzer, Clancy, Lapping, \& Zurbrugg, 2009; Oberholtzer et al., 2012; Jackson-Smith \& Sharp , 2008), there has been little documentation of the specific production and marketing adaptations scholars identified as important for RUI policy and economic investment. For example, Hart (1998) and Heimlich and Anderson (2001) identified and argued that highervalue crops that can be intensively produced on smaller acreages, such as fruit and vegetables, are more likely to persist at the RUI and contribute to the viability and resiliency of agriculture at the RUI (Hart, 1998; Heimlich \& Anderson, 2001). However, these statistics have not been updated or examined to understand changes in RUI agricultural production patterns.

In this paper we build on previous descriptive research to examine the degree to which these high-value production and marketing strategies assumed to thrive at the RUI (horse sales, nursery and greenhouse sales, recreation sales, organic sales, direct sales, community supported agriculture farms [CSAs], and value-added farms) are in fact doing so. Given the increasing recognition of the diversity of American farmers and ranchers (U.S. Department of Agriculture, National Agricultural Statistics Service [USDA, NASS], 2008), we take the analysis one step further to ask who are the farmers in these counties? Beyond types of production at the RUI, little has been documented on the social differences within the farm population itself, yet this can have bearings on policies designed to stabilize the production landscape (Inwood, Clark, \& Bean, 2013). There has been a rich tradition in rural studies examining the link between ethnicity, race, gender, and farm structure. At the community level the number of women in agriculture support groups is increasing, and at the national level the 2008 farm bill required 10 percent of funds be set aside for beginning and/or socially disadvantaged farmers and ranchers, and/or small and medium-sized farms and ranches (Hardesty, 2010). However, RUI scholars have largely neglected the relationship of farmer 
ethnicity, gender, and experience to farm structure and farm persistence.

Therefore, this paper answers two basic questions: (1) What is the spatial distribution of production and marketing practices assumed to play a role in the persistence and vitality of agriculture at the RUI? and (2) who are the farmers in these counties? We first review the literature examining agriculture at the RUI and farmer diversity, and then present the results of a descriptive analysis of high-value production and marketing systems using 2007 U.S. Census of Agriculture data.

\section{Literature Review}

Located beyond suburbia, the RUI is a mix of both rural and urban land uses and is socially and economically connected to an urban core (Audirac, 1999; Clark, McChesney, Munroe, \& Irwin, 2009). The RUI is a complex landscape and is affected by a variety of processes, including both global agrifood systems pressures and stresses from local nonfarm urban-related development. At the local level, direct influences from land competition and rising nonfarm population, and indirect influences such as rising land rents, taxes, and increased regulation create increased constraints on farming (Bryant \& Johnston, 1992; Fulton, Pendall, Nguyen, \& Harrison, 2001; Heimlich \& Anderson, 2001). Yet agricultural production at the RUI is substantial; RUI counties account for 78 percent of vegetable production and 91 percent of fruit production in the U.S. (AFT, 2013; Jackson-Smith \& Sharp, 2008).

An important theme implicit in many RUI models is the expectation that urban-oriented food and fiber production adaptation strategies (nursery and greenhouse, direct sales, horses, farmers' markets, CSAs, U-pick operations, agri-tourism, organic agriculture, etc.) are likely to emerge and succeed due to their proximity to urban markets (Bowler, 1999; Fennell \& Weaver, 1997; Heimlich \& Anderson, 2001; Lyson 2004). Heimlich and Brooks (1989) found a relationship between farm type and persistence at the RUI and identify three types of RUI farms, including (a) alternative enterprises (small in size with high-value outputs); (b) recreational enterprises (very small scale, operated by hobby farmers); and (c) traditional enterprises (large operations engaged in conventional commodity production). Research focusing on these various types of enterprises suggests that smaller-scale farms with higher-value outputs are the most likely to persist in metropolitan counties (Heimlich \& Anderson, 2001; Hoppe \& Korb, 2001). Alternative enterprise types can include consumer-oriented, entrepreneurial activities with an emphasis on direct marketing and value-adding. While there in fact has been a rise in the number of farms oriented toward local and alternative markets (Barbieri \& Mahoney, 2009; Inwood \& Sharp, 2012; Sparks, 2012), there has been little recent analysis to understand the spatial distribution of different types of specific urban oriented production and marketing systems across the RUI, particularly in agriculturally vibrant areas.

\section{Farmer Diversity at the RUI}

The structure of the farm business is not just a result of market and economic forces, but is shaped through the goals, values, and motivations of the farm family. These goals, values, and motivations are influenced by the demographic characteristics of the farm family (Colman \& Elbert, 1984; Gasson, 1973; Gasson \& Errington, 1993; Lobley \& Potter, 2004; Salamon, 1992; Shucksmith \& Herrmann, 2002). The associations among gender, ethnicity, culture, length of time farming, farm structure, and development have been well documented in the literature (Imbruce, 2007; Sachs, 1996; Salamon, 1992; Wells \& Gradwell, 2001.

Accounting for these differences is increasingly important considering the USDA, NASS report on the growing ethnic, racial, and gender diversity among U.S. farm and ranch operators, and the national investments being made in distinct subpopulations of farmers through the USDA Beginning Farmer and Rancher Grant Program, the National Immigrant Farming Initiative, and the Women's Agricultural Network. USDA, NASS (2007a) reported that from 2002 to 2007 the number of primary operator of all races and ethnic backgrounds increased by four percent, while the number of nonwhite operators grew at a faster rate. Operators reporting Hispanic origin increased 10 
percent from 2002 to 2007 (USDA, NASS, 2007a). The role of gender and sex and RUI farm development is particularly interesting. There was a 30 percent increase in female principle operators from 2002 to 2007 (NASS 2007a); however, a spatial analysis reveals that 31 percent of all metro area farms (using the 2008 U.S. Census metropolitan statistical area [MSA] definition) have female operators, compared to the national average of 14 percent of all farm operators. This increasing diversity of Hispanic, Asian, Native American, African American, beginning and women farmers reinforces the need to understand how social differences between farmers can influence farm structure at the RUI.

\section{Ethnicity and Race}

The association between ethnicity, culture, farm structure, and development was well documented by Salamon (1992), who identified a typology of Midwestern farmer types based on farm household ethnicities and their distinct agricultural or land ethics. Wells (1996) also has shown the linkage between ethnicity and farming subsystems in California strawberry production, finding that Japanese, Mexican and Anglo growers brought different sets of resources to their farms' development, and that the different social networks associated with each ethnic group created and reinforced farm management styles over time. Recent research on immigrant farmers from Southeast Asia in the Miami Metro region found that the unique motivations, social networks, and style of farming (intensive and diverse) has enabled these small family farms to thrive by taking advantage of niche markets and national distribution networks despite high land rents (Imbruce, 2007). The increase in the number of Hispanic, Asian, Native American and African American farmers (USDA, NASS, 2007a) reinforces the need to understand how cultural nuances influence larger production patterns on the RUI landscape.

\section{Gender and Sex}

There has been considerable interest in understanding the gendered dimension of farm adaptation and production strategies particularly as it relates to alternative agriculture (Chiappe \& Flora,
1998; Feldman \& Welsh, 1995; Sachs, 1996; Wells and Gradwell, 2001). Surveys of the wider female farm population have found women emphasize not only the environmental and economic benefits of sustainable agriculture, but are also more likely to emphasize the link between agriculture and community sustainability and well-being (Chiappe \& Flora, 1998; Feldman \& Welsh, 1995; Trauger, 2004; Trauger, Sachs, Barbercheck, Kiernan, Brasier, \& Findeis, 2008). Some of these gendered values have been correlated with specific farm structures, including the prevalence of, and preference for, cooperative farm markets, direct marketing, value-adding, and craft development among women operators as opposed to large-scale commodity agriculture activities. These trends are reinforced by McNally (2001), who found that when women participated in the active management of the farm operation, the probability of observing on-farm retailing and recreation enterprises increased by 12 percent.

The research examining gender, race, and ethnicity in relationship to farm structure reveal that each farmer subgroup has a unique history and cultural legacy that influence their goals, motivations, and values, which in turn influence the way they structure their farm and envision their farms' future. These studies demonstrate that the structure of a farm business (wholesale, direct marketing, organic, etc.) is not just the result of economic forces, but also reflects specific values and goals of the farm family. As farm, food, and land policies incorporate the social differences of farmers, it is useful to understand how different subpopulations of farmers are spatially distributed across the RUI and non-RUI landscape.

\section{Methods}

To document urban-oriented production at the RUI, we first identified RUI counties. Counties in the U.S. were categorized as Metro and Nonmetro using the current U.S. Census definition. Metro counties are used as a proxy for the RUI, as metro counties are composed of central urban cores and include counties that contain rural lands, but have social and economic ties (measured by commuting patterns) to the urban core (Berube \& Forman, 2002; Wolman, Galster, Hanson, Ratcliffe, Furdell, 
\& Sarzynski, 2005). To capture meaningful production at the RUI, counties were then classified as agriculturally important (AI) or non-agriculturally important (NAI), using an approach akin to the parameters described by Jackson-Smith and Jensen (2009). AI counties are in the top three quartiles of U.S. agricultural sales in 2007 and exhibit a healthy agricultural sector. Agricultural sales for NAI counties ranged from US $\$ 0$ to US $\$ 19,379,000$ in 2007. AI county sales in 2007 ranged from US $\$ 19,386,000$ to US $\$ 3,730,546,000$. As an indicator, $\mathrm{AI}$ uses the market value of agricultural product sold and the intensity of production measured via sales per acre of total farmland and cropland. Compared to the ERS farm-dependent county classification, the AI indicator is better able to pick up more intensive uses of farmland and agricultural output regardless of whether a county is large or small, or urban or rural, or if the regional economy is highly specialized or diversified (Jackson-Smith \& Jensen, 2009).

We then classified counties as Metro-AI, Metro-NAI, Nonmetro-AI, or Nonmetro-NAI to achieve a more refined analysis for examining spatial distributions of specific production practices. We recognize classifying counties as AI or NAI introduces bias into the analysis, as a larger number of sales will automatically come from AI counties. While this bias does exist, the results are not necessarily predetermined. In fact, this classification brings forward subtle nuances that would have been overlooked if the analysis only focused on Metro versus Nonmetro.

The number of farms and sales values for horses, nursery and greenhouse, recreational services, organic agriculture, direct marketing, CSAs, and value-added production were obtained for each county $(n=3080)$ in the U.S. from the 2007 U.S. Census of Agriculture. Descriptive statistics (totals and percentages) were run to examine the distribution of these variables between the different county types. Due to the relatively small number of farms engaging in some of these activities,
Table 2. Percent of Counties, Farms and Sales by Metro and Agriculturally Importance (AI) or Non-agriculturally Important (NAI) Status, 2007

\begin{tabular}{lccccc}
\hline & Metro-Al & Nonmetro-Al & Metro-NAl & Nonmetro-NAl & Total \\
\hline Counties & $25.0 \%$ & $48.5 \%$ & $9.8 \%$ & $16.7 \%$ & $100 \%$ \\
\hline Farms & $35.8 \%$ & $50.8 \%$ & $5.1 \%$ & $8.3 \%$ & $100 \%$ \\
\hline Sales & $38.1 \%$ & $59.7 \%$ & $0.8 \%$ & $1.4 \%$ & $100 \%$ \\
\hline
\end{tabular}

Table 1. Frequency and Percent of Metro and Agriculturally Important (AI) Counties, 2007

\begin{tabular}{lcc}
\hline Counties & Frequency & Percent \\
\hline Metro & 1,071 & $34.8 \%$ \\
\hline Nonmetro & 2,009 & $65.2 \%$ \\
\hline Total & 3,080 & $100 \%$ \\
\hline Al & 2,263 & $73.5 \%$ \\
\hline Non-Al & 817 & $26.5 \%$ \\
\hline Total & 3,080 & $100 \%$ \\
\hline
\end{tabular}

sales data was suppressed for some counties. In this paper suppressed sales are treated as missing. Initial analysis revealed the significance of California in organic production and direct sales. To better understand the spatial distribution of organic agriculture and direct sales, California was treated separately in the analysis in some cases. Finally, to understand if there is a spatial dimension to the increasing diversity of American farmers, we examined farmer demographics including race, sex, and beginning farmers. Finally, mapping the variables with GIS illustrates the regional patterns of the statistical findings.

\section{Results}

The majority of U.S. counties are Nonmetro counties (65.2 percent) and are non-agriculturally important (73.5 percent) (table 1). Comparatively, Metro counties account for 34.8 percent of all counties, while agriculturally important (AI) counties represent only 26.5 percent of all counties. Table 2 presents the distribution of counties, farm and sales by Metro-AI status and demonstrates the significance of Metro-AI agriculture compared to Nonmetro-AI, Metro-NAI, and Nonmetro-NAI. Figure 1 illustrates the spatial distribution of these counties. Nonmetro-AI counties make up the 
largest share of counties (48.5 percent), sales (59.7 percent) and farms (50.8 percent). While Metro-AI counties only represent 25 percent of all counties, they account for 38.1 percent of all U.S. sales and 35.8 percent of U.S. farms; these significant contributions to the U.S. agricultural economy reinforce the need to understand the nuances of RUI agriculture.

\section{Horse Sales, Nursery and Greenhouse,} and Recreation Sales

Horses, nursery and greenhouse products, and farm and ranch-based recreation are specific products and services that have been assumed and promoted to do well in areas proximate to urban populations. Horses are not considered a food or fiber commodity, and the degree to which horses should be formally counted in the agricultural sector has been debated. Nationally the horse industry directly contributes US $\$ 39$ billion into the U.S. economy through feed crops, bedding, breeding, sales, racing, recreation, tourism, and shows (American Horse Council, 2005; Whiting, McCall, \& Molnar , 2005). This analysis found that horse sales are concentrated in metropolitan counties and
Table 3. Top 10 Horse Counties by Sales, 2007

\begin{tabular}{llcr}
\hline County Type* $^{*}$ & County & Farms & \multicolumn{1}{c}{ Sales (US\$) } \\
\hline Metro-Al & Fayette, Kentucky & 249 & $\$ 409,617,000$ \\
\hline Metro-Al & Woodford, Kentucky & 190 & $\$ 212,610,000$ \\
\hline Metro-Al & Marion, Florida & 847 & $\$ 128,244,000$ \\
\hline Metro-Al & Bourbon, Kentucky & 177 & $\$ 120,779,000$ \\
\hline Metro-Al & Jessamine, Kentucky & 81 & $\$ 96,208,000$ \\
\hline Metro-Al & Scott, Kentucky & 136 & $\$ 45,553,000$ \\
\hline Metro-Al & Monmouth, New Jersey & 154 & $\$ 17,257,000$ \\
\hline Metro-Al & Chester, Pennsylvania & 206 & $\$ 12,953,000$ \\
\hline Metro-Al & Fauquier, Virginia & 146 & $\$ 10,641,000$ \\
\hline Metro-Al & San Diego, California & 258 & $\$ 9,609,000$ \\
\hline
\end{tabular}

* Al = Agriculturally Important county 
Figure 2. Horse, Nursery and Greenhouse, Tourism, and Recreation Sales by County Type, 2007

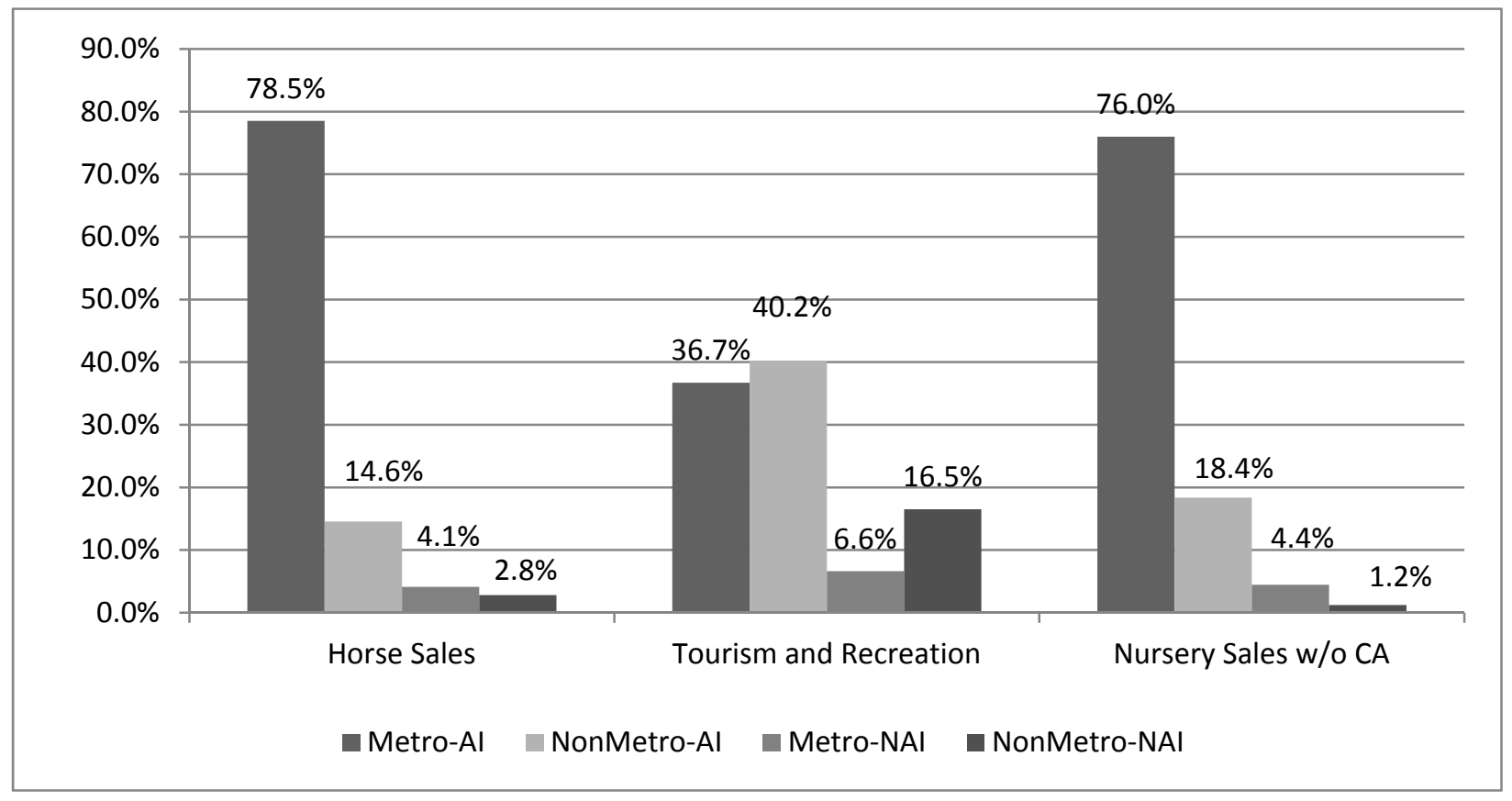

town of Ocala is one of the major thoroughbred industry centers (table 3). The emergence of regional horse industries at the RUI demonstrates how an agricultural sector can be tightly tied to the larger regional economy.

Nursery and greenhouse operations are defined as production sites that are protected

Table 4. Top 10 Nursery and Greenhouse Counties by Sales Without California, 2007

\begin{tabular}{llcc}
\hline County Type* & County & $\begin{array}{c}\text { Nursery and } \\
\text { Greenhouse } \\
\text { Farms }\end{array}$ & $\begin{array}{c}\text { Nursery and } \\
\text { Greenhouse Sales } \\
(\text { US } \$)\end{array}$ \\
\hline Metro-Al & Miami-Dade, Florida & 838 & $\$ 493,710,000$ \\
\hline Metro-Al & Chester, Pennsylvania & 186 & $\$ 402,195,000$ \\
\hline Metro-Al & Marion, Oregon & 365 & $\$ 243,693,000$ \\
\hline Metro-Al & Orange, Florida & 261 & $\$ 237,605,000$ \\
\hline Metro-Al & Clackamas, Oregon & 638 & $\$ 227,114,000$ \\
\hline Metro-Al & Washington, Oregon & 293 & $\$ 199,317,000$ \\
\hline Metro-Al & Palm Beach, Florida & 425 & $\$ 185,151,000$ \\
\hline Metro-Al & Suffolk, New York & 254 & $\$ 182,901,000$ \\
\hline Metro-Al & Maricopa, Arizona & 112 & $\$ 168,405,000$ \\
\hline Metro-Al & Lake, Florida & 246 & $\$ 141,702,000$ \\
\hline
\end{tabular}

* Al = Agriculturally Important county under glass or other types of material, and sell terrestrial and aquatic plants, trees, shrubs, bulbs, tubers, seeds, fruits, berries, herbs, trees, starts, sod, etc. As relatively small acreage operations with high value outputs, nursery and greenhouse operations appear to be ideally suited for the RUI. These operations serve the high demand for landscaping shrubs, trees, ornamental flowers, and vegetable starts coming from proximate suburban and urban markets. The 2007 Census of Agriculture counted 54,889 nursery and greenhouse operations accounting for US $\$ 16.6$ billion in agricultural sales (USDA, NASS, 2007b). California alone accounts for 25 percent of nursery and greenhouse sales.

To understand California's impact, the analysis was run both with and without California. In each case nursery and greenhouse sales are predominantly concentrated in Metro and AI counties. Without 
California, over three-quarters (76 percent) of nursery and greenhouse sales occur in Metro counties; the value increases to 84.7 percent when California is included, compared to only 18.4 percent in Nonmetro counties (figure 2). Just over 94 percent of nursery and greenhouse sales are concentrated in AI counties. With and without California, all of the top 10 counties for nursery and greenhouse sales are Metro-AI. With California, five of the top 10 are California counties. The predominance of California, Florida, and Oregon counties reflects the important role climate plays in production location (table 4). The more moderate and longer growing season in these regional production centers have led to extensive national and regional distribution networks that supply local nursery and greenhouse operations across the country.

The Census of Agriculture definition of recreational services is extremely expansive, as it includes income from services such as hunting, fishing, farm or wine tours, hay rides, u-pick operations, and more (USDA, NASS, 2007b). There was a 17 percent decrease in the number of farms offering recreational services between 2002 and 2007, but the income generated from these activities increased 236 percent between these same years, with farms reporting an average of US $\$ 24,276$ in recreational

\section{Figure 3. Spatial Distribution of Recreational Farms, 2007}

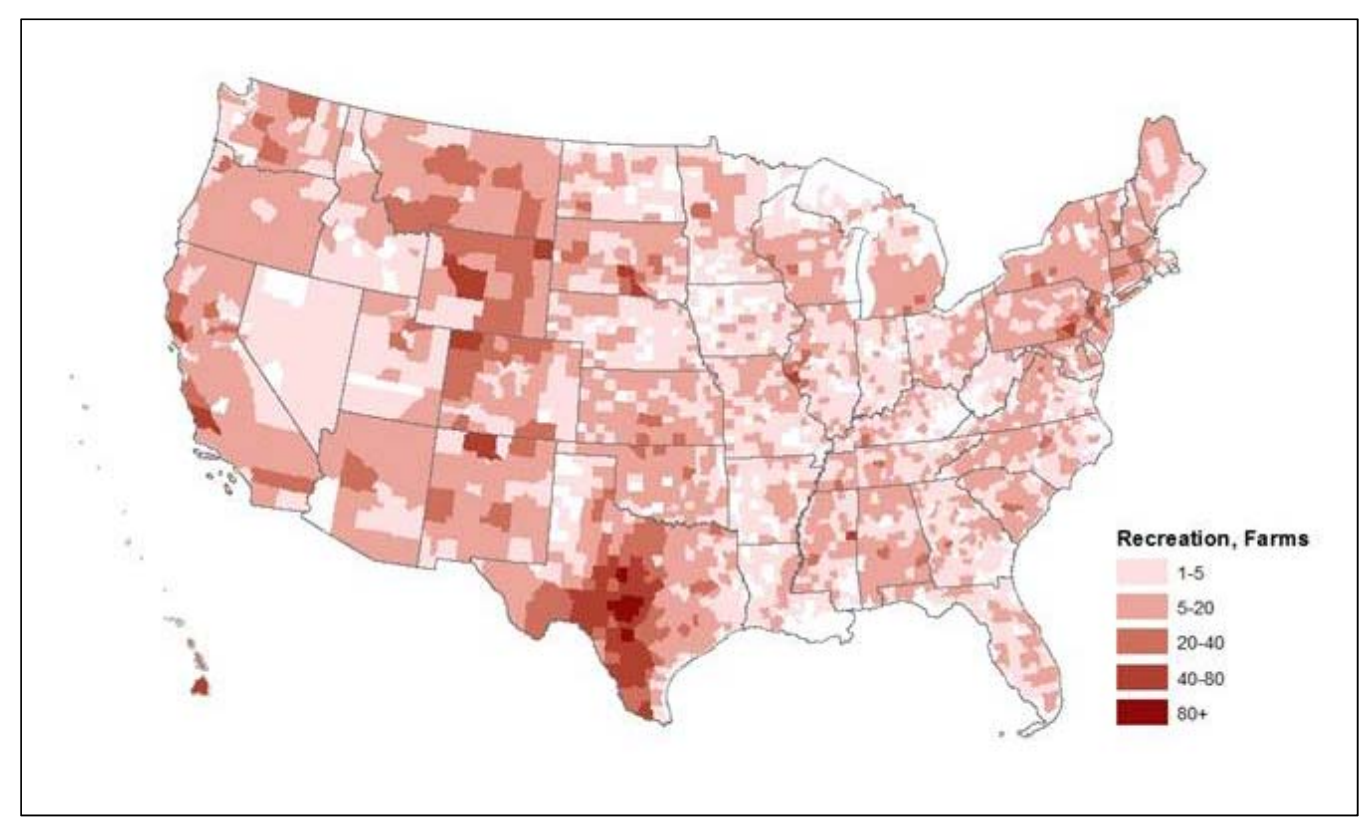


Journal of Agriculture, Food Systems, and Community Development

ISSN: 2152-0801 online

www.AgDevJournal.com

Table 6. Organic and Direct Sales by County Type With and Without California, 2007

\begin{tabular}{lccccc}
\hline & Metro-Al & Nonmetro-Al & Metro-NAl & Nonmetro-NAI & Total \\
\hline Organic Sales & $67.2 \%$ & $30.6 \%$ & $0.4 \%$ & $1.8 \%$ & $100 \%$ \\
\hline Organic Sales Without California & $47.1 \%$ & $48.9 \%$ & $0.8 \%$ & $3.2 \%$ & $100 \%$ \\
\hline Direct Sales & $60.9 \%$ & $28.5 \%$ & $5.7 \%$ & $4.9 \%$ & $100 \%$ \\
\hline Direct Sales without California & $55.3 \%$ & $32.4 \%$ & $6.6 \%$ & $5.6 \%$ & $100 \%$ \\
\hline
\end{tabular}

* NAI = Non-agriculturally Important county; AI = Agriculturally Important county

coming from more remote counties. This reflects the more traditional forms of outdoor recreation farms and ranches can offer, including hunting, fishing, birding, and horseback riding. The top 10 counties for recreational sales are an eclectic mix and mirror high-amenity landscapes such as those found in Hawaii, New Mexico, and the Finger Lakes region of New York state. The predominance of counties located in Texas, Wyoming, and Colorado reflect the historical recreation opportunities farms and ranches offer in the West (table 5 and figure 3).

\section{Organic and Direct Sales}

In the U.S. the upward trend of organic sales and direct marketing has continued to increase. The USDA 2008 Organic Production Survey (an addendum to the Census of Agriculture) counted 14,540 organic farms and ranches in the U.S. representing 4.1 million acres or 1.7 million hectares of land (USDA, NASS, 2008). Organic farmers (certified

Table 7. Top 10 Counties with Organic Sales Excluding California, 2007

\begin{tabular}{llcc}
\hline Type & County & Farms & Sales (US\$) \\
\hline Metro-Al & Maricopa, AZ & 24 & $\$ 24,193,000$ \\
\hline Metro-Al & Benton, WA & 36 & $\$ 24,004,000$ \\
\hline Nonmetro-Al & Grant, WA & 37 & $\$ 23,062,000$ \\
\hline Metro-Al & Chelan, WA & 46 & $\$ 19,670,000$ \\
\hline Nonmetro-Al & Klamath, OR & 42 & $\$ 18,696,000$ \\
\hline Metro-Al & Chester, PA & 38 & $\$ 18,306,000$ \\
\hline Metro-Al & Yuma, AZ & 10 & $\$ 15,208,000$ \\
\hline Metro-Al & Yamhill, Oregon & 72 & $\$ 13,909,000$ \\
\hline Metro-Al & Yakima, Washington & 95 & $\$ 13,237,000$ \\
\hline Metro-Al & Lancaster, Pennsylvania & 98 & $\$ 11,687,000$ \\
\hline
\end{tabular}

* Al = Agriculturally Important county and exempt organic farms) reported US $\$ 3.16$ billion in total sales, with US\$1.94 billion in crop sales and US $\$ 1.22$ billion in livestock, poultry, and their products (USDA, NASS, 2008). The economic contribution of organic agriculture is significant to U.S. farm households as organic farms reported higher average annual sales (US\$217,675) compared to the overall national average (US\$134,807) (USDA, NASS, 2008).

In regard to direct sales, 136,9817 farms reported selling agricultural products directly for human consumption in 2007, representing a 17.2 percent increase from 2002 (USDA, NASS, 2008). Nationally, farmers reported US\$1.21 billion dollars in direct sales, accounting for 0.4 percent of total U.S. sales (USDA, NASS, 2008). The vast majority of farms reporting direct sales (93.3 percent) were small family farms (whose total sales are less than US\$250,000) (USDA, NASS, 2008). Taken together, California, New York, and Pennsylvania account for over a quarter (26.1 percent) of all direct sales (USDA, NASS, 2008). Given the disproportionate influence of California, with just under half (45.5 percent) of all certified organic production and 14.2 percent of direct sales in the U.S. coming from the state, we included and excluded California in the tallies to see if there were any major differences.

\section{Organic Sales}

When California is included in the analysis, the majority of organic sales are a Metro and 
AI phenomena, with the vast majority of sales (67.2 percent) concentrated in Metro-AI counties (table 6). When California is excluded from the analysis, organic production is still predominantly concentrated in AI counties (96 percent); however, it is no longer primarily located in metropolitan counties. Without California, organic production is fairly evenly split between Metro (47.1 percent) and Nonmetro (48.9 percent) counties. The fact that Nonmetro and AI counties stand out as sites of substantial organic production (controlling for the role of California) supports the industrialization-oforganics argument where existing commodity systems are shifting into organic production (Guthman, 2004). Regionally, the top 10 counties by sales and farms are dominated by California. Excluding California, the top counties reflect a greater geographical diversity that corresponds to the particular organic commodity, such as organic grain production in eastern Washington and dairy and vegetable production in Arizona (table 7). In addition to the presence of organic commodity production, the high number of organic farms in the Northeast (figure 4) may be reflecting a variety of factors, including the large demand for organic products in the region, the significant role organic price premiums have in supporting dairy farms in the Northeast (Parsons, 2011), and the strength of the Northeast Organic Food and Farming Association, which over the years has become one of the major stakeholder and technical-assistance nonprofit organizations in the region.

\section{Direct Sales}

Both including and excluding California, direct sales occur more frequently in Metro and AI counties. Including California, only one-third (33.5 percent) of direct sales are from Nonmetro counties, while 66.5 percent are concentrated in metro regions; these numbers change only modestly when excluding California. Direct sales are also primarily being generated in AI counties (89.4 percent including California and 87.8 percent excluding California). It is interesting to note that, excluding California, NAI counties account for 12.2 percent of direct sales; when including California, the amount drops negligibly. California counties represented five of the top 10 farms with direct sales. When California is removed from the analysis, direct sales tend to be most common in Metro-AI East coast counties with the exception of Addison, Vermont (Nonmetro-AI), a highly productive agricultural region in Vermont, a state with a highly developed community-based food and agriculture system (see table 8 and figure 5). Nationally, the Northeast has been a leader in developing farmland protection policy and innovative buy local marketing campaigns. These results demonstrate the nuance of how a state like 
California, with such an intensive production system, can mask other regional patterns and obscure how land use policies and marketing programs can support farmers in especially tight land markets, like those found in the Northeast.

\section{CSA and Value-Added}

\section{Farms}

The number of community supported agriculture (CSA) operations has continued to increase. The 2007 Census of Agriculture counted 12,549 farms selling their products through CSAs (USDA, NASS, 2007b). The census only records number of CSA farms; it does not record sales data. In this analysis the majority of CSA farms were in Nonmetro counties and in AI counties. There were slightly more CSA farms in Nonmetro-AI counties (43.8\%) compared to Metro-AI (41.6\%) (table 9). Less than 15 percent of all CSA farms were located in Non-AI counties with slightly more in Nonmetro-NAI (8.4\%) compared to Metro-NAI $(6.2 \%)$. While the overall pattern reveals there are more CSA farms in Nonmetro counties, the top 10 counties with CSA farms are predominantly found in Metro counties, particularly in California and in the Northeast, the
Figure 5. Spatial Distribution of Direct Marketing Farms, 2007

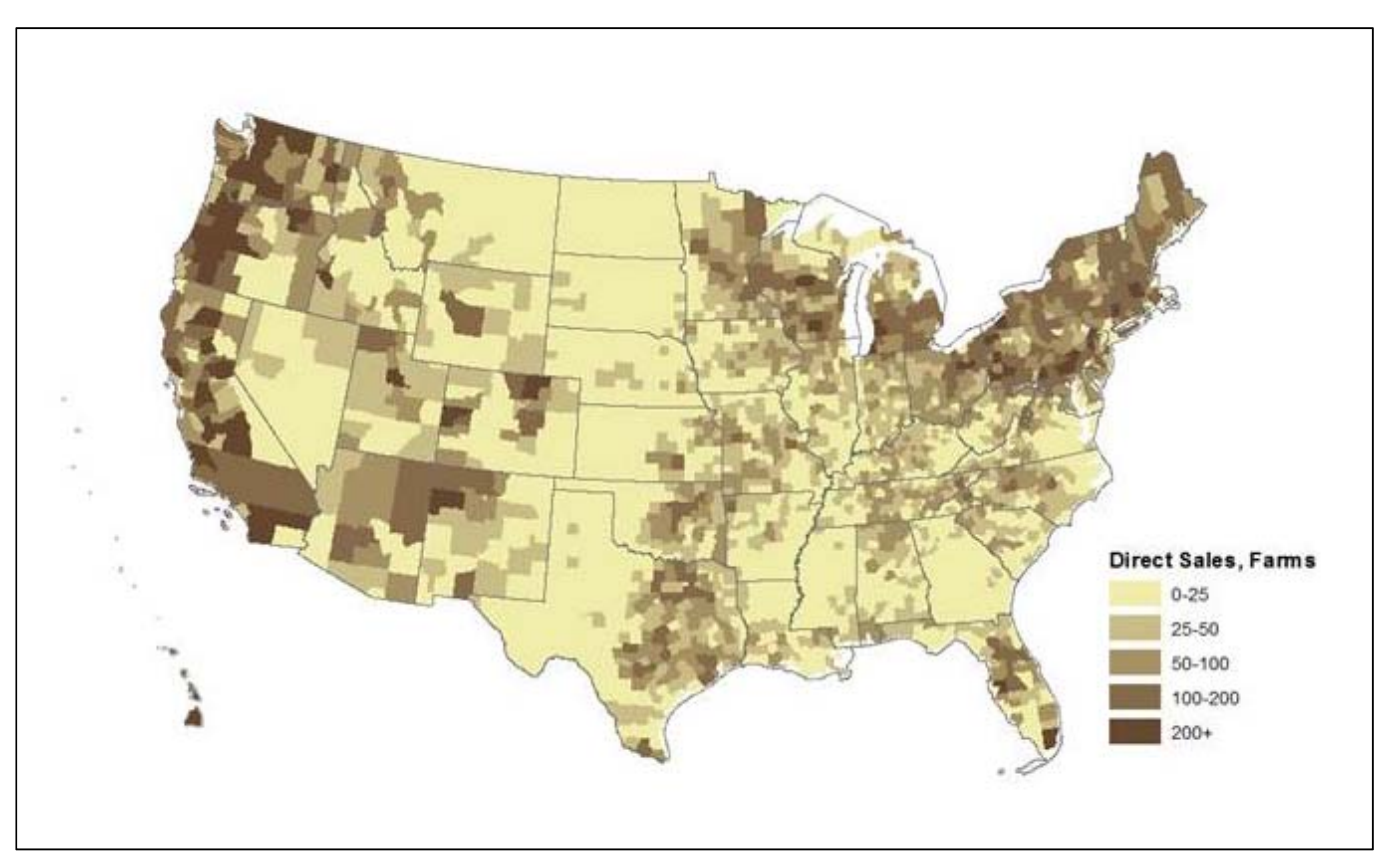


Table 9. CSA and Value-Added Farms by County Type, 2007

\begin{tabular}{lccccc}
\hline & Metro-Al & Nonmetro-Al & Metro-NAl & Nonmetro-NAI & Total \\
\hline CSA Farms & $41.6 \%$ & $43.8 \%$ & $6.2 \%$ & $8.4 \%$ & $100 \%$ \\
\hline Value-Added Farms & $38.3 \%$ & $46.2 \%$ & $6.2 \%$ & $9.3 \%$ & $100 \%$ \\
\hline
\end{tabular}

* NAI = Non-agriculturally Important county; AI = Agriculturally Important county

Table 10. Top 10 Counties with CSA Farms, 2007

\begin{tabular}{llc}
\hline County & Al Status & $\begin{array}{c}\text { Number of } \\
\text { Farms }\end{array}$ \\
\hline San Diego, California & Metro-Al & 79 \\
\hline Tulare, California & Metro-Al & 61 \\
\hline Fresno, California & Metro-Al & 59 \\
\hline $\begin{array}{l}\text { San Luis Obispo, } \\
\text { California }\end{array}$ & Metro-Al & 54 \\
\hline Ventura, California & Metro-Al & 52 \\
\hline Hawaii, Hawaii & Nonmetro-Al & 48 \\
\hline Middlesex, & Metro-Al & 48 \\
Massachusetts & Metro-Al & 47 \\
\hline Lancaster, Pennsylvania & Metro-Al & 44 \\
\hline Sonoma, California & Metro-Al & 43 \\
\hline Franklin, Massachusetts & M &
\end{tabular}

* Al = Agriculturally Important county

for CSA farms, value-added farms tend to be found in Nonmetro counties. While the majority of value-added farms are in AI counties, there are a greater number of farms in Nonmetro-AI regions (46.2\%) compared to Metro-AI counties (38.3\%) (table 9). Again, 15 percent of value-added farms are found in Non-AI counties, with a slight majority in Nonmetro-NAI $(9.3 \%)$ compared to Metro-NAI (6.2\%). The top 10 counties with value-added farms are in largely Metro-AI counties, with a large number in Oregon reflecting the investment in the processing associated with the berry, wine, cheese, and turf-grass industries in the state (table 11).

\section{Farmer Demographics}

Each subgroup of farmers has a unique historical and cultural heritage. Recognizing these differences is important for understanding how different types of farmers are able to access information,
Table 11. Top 10 Counties with Value-Added Farms, 2007

\begin{tabular}{lcc}
\hline County & Al Status & $\begin{array}{c}\text { Number of } \\
\text { Farms }\end{array}$ \\
\hline Hawaii, Hawaii & Nonmetro-Al & 266 \\
\hline Clackamas, Oregon & Metro-Al & 257 \\
\hline Lancaster, & Metro-Al & 256 \\
\hline Pennsylvania & Metro-Al & 229 \\
\hline Lane, Oregon & Metro-Al & 184 \\
\hline Yamhill, Oregon & Metro-Al & 183 \\
\hline Jackson, Oregon & Metro-Al & 179 \\
\hline Weld, Colorado & Metro-Al & 167 \\
\hline Marion, Oregon & Nonmetro-Al & 166 \\
\hline Douglas, Oregon & Metro-Al & 164 \\
\hline Sonoma, California &
\end{tabular}

* Al = Agriculturally Important county

resources, and land, all of which in turn influence farm structure and farm viability.

As expected, the majority of all farmers are located in AI counties. However, a closer look reveals the nuances in the geographic distribution of different populations of farmers. The majority of Asian farmers (60.3 percent) and farmers of Spanish, Hispanic, or Latino origin (51 percent) are located in Metro-AI counties (table 12). Just under half of African American/Black farmers (46.5 percent) are located in Nonmetro-AI counties and 33.7 percent are in Metro-AI counties. Though not a majority, it is interesting to note that a substantial portion of Hispanic farmers (14.1 percent) and African American farmers (12.5 percent) are farming in Nonmetro-NAI counties. Nearly half of all operators reporting more than one race (49.3 percent) are farming in Nonmetro-AI counties, and 36.2 percent are farming in Metro-AI counties. Over one-third of women operators (38 percent) 
Table 12. Farmer Demographics by County Type, 2007

\begin{tabular}{lccccc}
\hline Operator & Metro-Al & Nonmetro-Al & Metro-NAI & Nonmetro-NAI & Total \\
\hline Asian & $60.3 \%$ & $34.2 \%$ & $3.1 \%$ & $2.4 \%$ & $100 \%$ \\
\hline Hispanic & $51.0 \%$ & $30.9 \%$ & $4.0 \%$ & $14.1 \%$ & $100 \%$ \\
\hline African American & $33.7 \%$ & $46.5 \%$ & $7.3 \%$ & $12.5 \%$ & $100 \%$ \\
\hline Native American & $23.9 \%$ & $44.0 \%$ & $6.8 \%$ & $25.2 \%$ & $100 \%$ \\
\hline Native-Hawaiian & $36.0 \%$ & $57.7 \%$ & $2.7 \%$ & $3.6 \%$ & $100 \%$ \\
\hline More Than One Race & $36.2 \%$ & $49.3 \%$ & $5.4 \%$ & $9.1 \%$ & $100 \%$ \\
\hline Woman & $38.0 \%$ & $47.6 \%$ & $5.7 \%$ & $8.7 \%$ & $100 \%$ \\
\hline Beginning Farmer (less than 10 years) & $37.5 \%$ & $48.3 \%$ & $5.5 \%$ & $8.7 \%$ & $100 \%$ \\
\hline
\end{tabular}

* NAI = Non-agriculturally Important county; Al = Agriculturally Important county

and beginning farmers ( 37.5 percent) are located in Metro-AI counties.

Spatially, African American farmers are concentrated in the Southeastern U.S. along the Black Belt, a term that refers to the portion of the deep South that was once characterized by planation agriculture in the $19^{\text {th }}$ century, and where today African American communities are disproportionally affected by acute poverty (figure 6 ). In contrast, Hispanic farmers are concentrated in the Southwest and in Florida where the majority of the Hispanics in the U.S. live (U.S. Census, 2013 (figure 7), while the spatial distribution of women

\section{Figure 6. Spatial Distribution of African American Farmers, 2007}

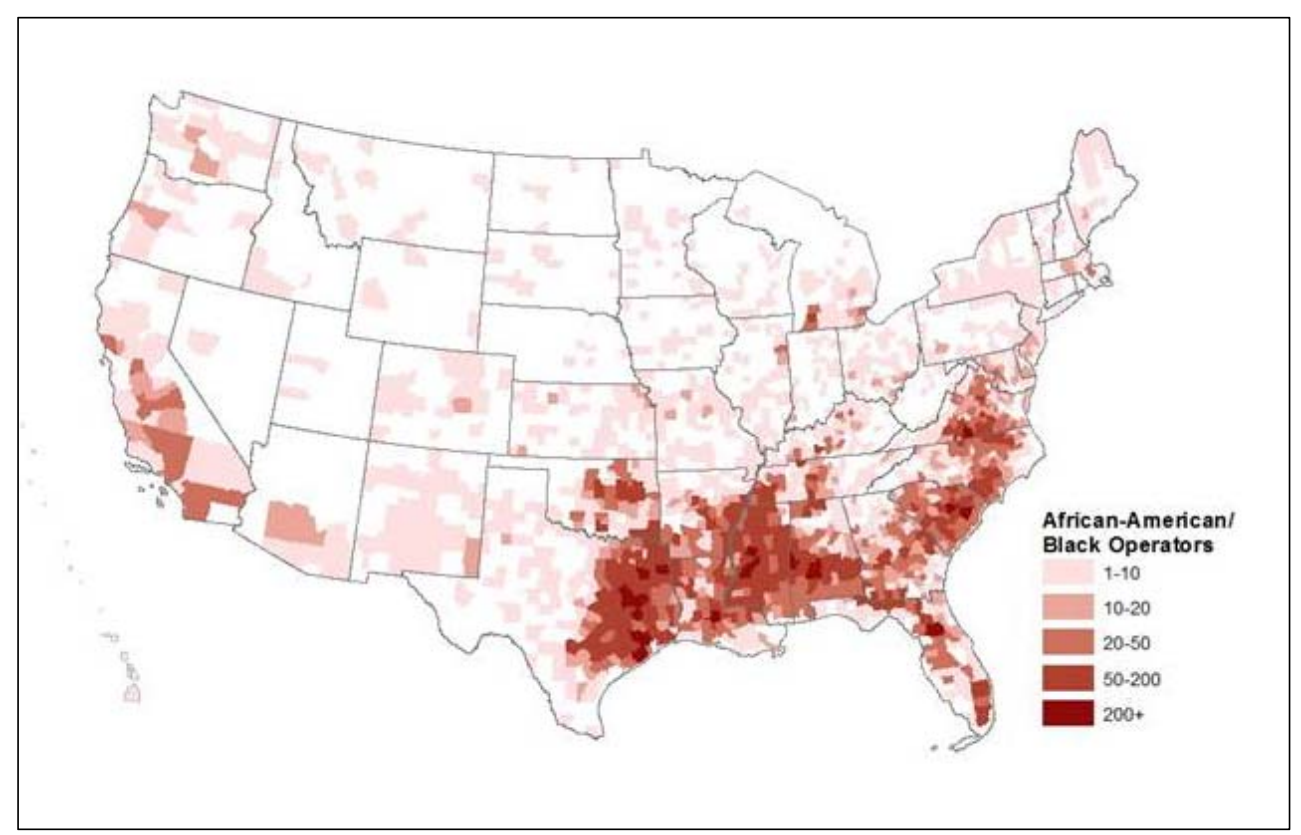

and beginning farmers is fairly even across the U.S.

The U.S. Census of Agriculture recognizes two groups of native peoples, Native Americans (including Native Alaskans when reported) and Native Hawaiians or Other Pacific Islander. Both groups have a history of protracted land disputes with the U.S. government. Native American farmers are much more likely to be producing in Nonmetro-AI counties (44 percent) than in MetroAI counties (23.9 percent), while a quarter (25.2 percent) of Native American farmers are located in Nonmetro-NAI counties. This finding most likely reflects the location of Native American reservations, which have historically been on marginalized lands. Over half of Native Hawaiian farmers (57.7 percent) are located in Nonmetro-AI counties and 36 percent are in Metro-AI counties. This finding most likely reflects the displacement of Native Hawaiians off the island of Oahu (the major metro island in Hawaii) as lands were lost through legal land contracts 
rather than

forced dis-

placement

through mili-

tary action

(Levy, 1975).

\section{Discussion}

This paper

provides an

updated

analysis of

metropolitan

agriculture by

(1) examining

whether the

production

and market-

ing strategies

anticipated to
Figure 7. Spatial Distribution of Hispanic Farmers, 2007

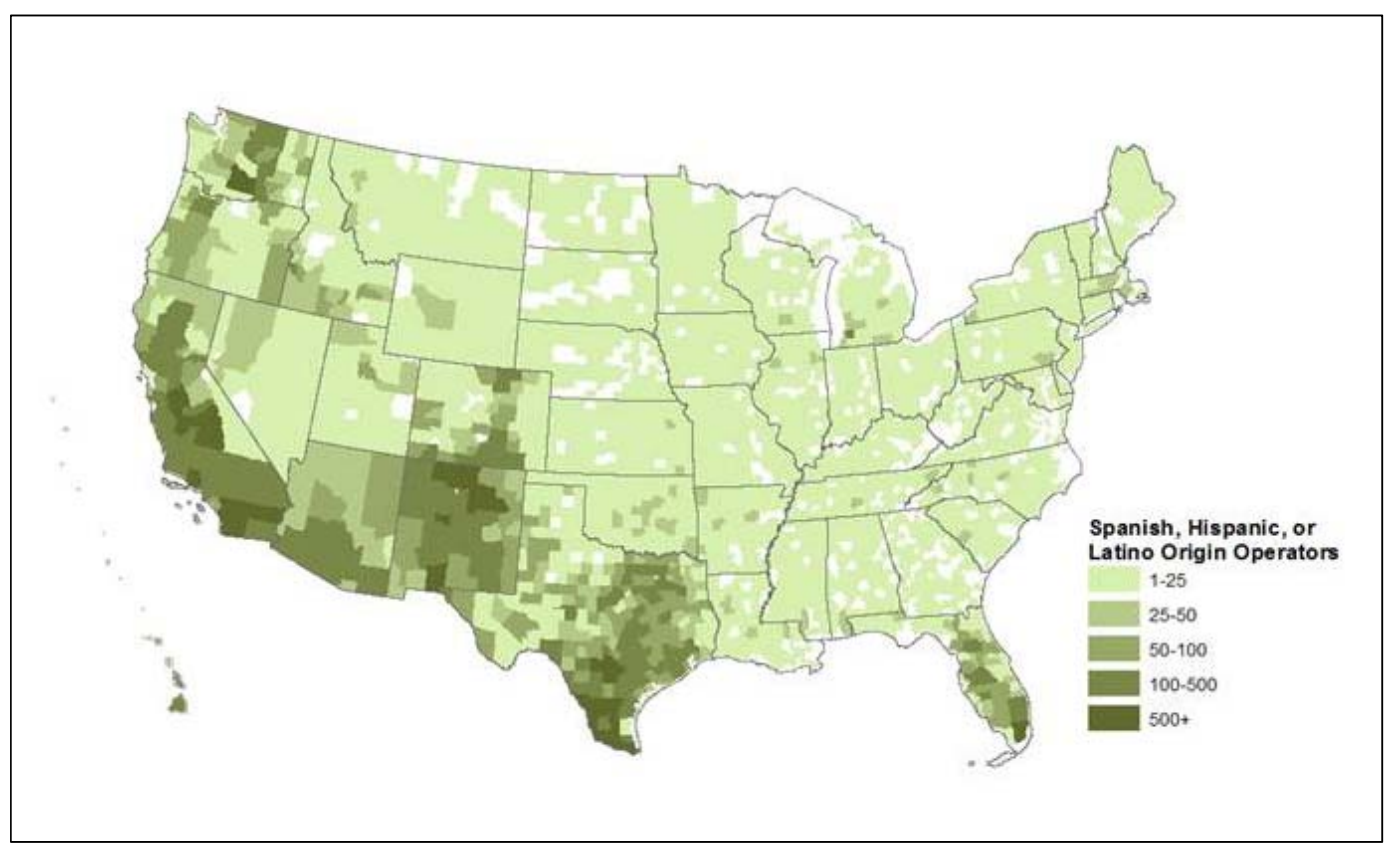

succeed at

the RUI are in fact concentrated at the RUI; (2) refining the analysis to account for the degree to which Metro and Nonmetro counties are agriculturally important (or not agriculturally important); and (3) including an analysis of the distribution of producer demographics.

We find that despite the threats from nonfarm development, farming at the RUI continues to significantly contribute to the U.S. agricultural economy. The persistence of agriculture at the RUI is a reflection of community and government efforts, land use policies, marketing programs, and decisions and adaptations made by individual farm families. Due to the design of the analysis, a greater number of sales were concentrated in AI counties compared to NAI counties. However, not all types of high-value production and marketing systems assumed to dominate in metropolitan regions were found in Metro-AI counties as one would expect. Horses, nursery and greenhouse, and direct sales were more prevalent in Metro regions, while organic production, recreation sales, CSA farms, and value-added farms were more likely to be concentrated in Nonmetro counties.

The analysis demonstrated that certain types of high-value production systems that directly feed into consumer needs and interests, such as horses and nursery and greenhouse, do in fact thrive at the RUI. However, the spatial concentration of these sectors in the RUI is also partially a reflection of their connection to larger regional economies. In the case of horses, the counties with the highest horse sales are also major horse-breeding and horse-racing centers. Parallel to horses, nursery and greenhouse production predominates in areas with a milder climate and longer growing season that supply other nurseries across the country that are in cooler climates with shorter growing seasons.

The vast majority of direct sales are in MetroAI counties. When California is taken out of the analysis, the high number of counties with direct sales in the Northeast demonstrates the role that investments in community-based local food and regional food systems can have. A substantial number of direct sales are in Nonmetro-AI areas, and a small, but present, number are in NAI counties. This finding may reflect the challenge of disaggregating the different types of direct sales the census of agriculture captures under this one variable (Lev \& Gwin, 2010). Lev and Gwin (2010) note that livestock farmers are the majority of direct marketers (58 percent), but only account for 31 percent of direct marketing sales. Following up on Lev and Gwin's (2010) recommendations, as 
federal policy focuses increasingly on local food systems, it important to evaluate whether more refined data points are needed in order to more accurately measure different types of direct marketing.

Additionally, this analysis examined how a state like California, which produces a large volume of high-value crops and has a significant number of RUI counties, can obscure other regional production patterns. Accounting for the effect of California enables RUI researchers to develop a more nuanced policy analysis when examining production and marketing patterns across the country.

While farms just outside cities may be increasing the number of recreational opportunities they offer through agri-tainment initiatives, this analysis revealed that the bulk of recreational sales are coming from counties that have other outdoor recreation activities and scenic amenities, particularly in the West. Future research should examine how recreational sales play into multifunctional agricultural initiatives particularly at the RUI.

Organic products command a higher premium price. In this analysis organic sales were more concentrated in Nonmetro (taking out California) and AI counties, most likely reflecting the shift of commodity sectors into organic production. This follows the findings of the 2008 USDA Organic Production Survey, which found that 83 percent of organic sales are to wholesale markets (processors, millers, packers, distributors, wholesalers, brokers or repackers), while 10.6 percent are to direct-toretail and only 6.8 percent of sales are from directto-customer exchanges (farm stands, u-pick, farmers' markets and CSAs) (USDA, NASS, 2008). Organic agriculture is important for soil health and ecosystem services, and can significantly contribute to farmer income and farm viability, particularly by adding value to commodity crops. However, organic as a production method itself may not be directly contributing to the economic vitality of RUI agriculture compared to broader local and regional food system development initiatives.

The RUI is a highly heterogeneous place, both in terms of production and farmer demographics. Currently the majority of RUI policies, programs, and campaigns focus on land policy and market diversity, and do not recognize social differences among farmers. Nor do these efforts recognize how cultural and historical legacies may enhance or complicate many of the initiatives directed towards agriculture at the RUI. As new policies and programs are developed to support different types of farmers, it is important to reflect on how the objectives and intended people-based outcomes match up to where the targeted farmers are located. This analysis demonstrated that farmers at the RUI are extremely diverse. However, it also found there are a substantial number of beginning and women farmers in Nonmetro-AI counties, and a small but notable number of African American, Hispanic and Native American farmers in Nonmetro-NAI counties. These findings reinforce the need for policy-makers and NGOs to analyze how specific initiatives will affect different types of farmers in different locations.

\section{Conclusion}

The now mainstream interest in economic development through food and agriculture and in local and regional food systems has brought a new focus to both the significance of agricultural at the RUI and to the need for additional investment in these regions. Policy-making is often about resource distribution, and given the limited financial resources available, farm advocacy organizations, researchers, and policy- and grant-makers need baseline data to inform their priorities. This paper informs these debates by documenting current production and marketing systems assumed to thrive in agriculturally important RUI counties. We find that urban and consumer-oriented production and marketing systems are not just metro phenomena, but in fact are more prevalent in nonmetropolitan regions as in the case of organic agriculture and recreational sales. These findings, in combination with the regional distribution of nursery and greenhouse and horse sales, demonstrate that policy-makers need to take regional economies, climate, and distribution networks into account when establishing investment priorities. Future research should expand these initial observations to more closely examine the regional dimension to these production and marketing systems.

This paper also provides new information on the spatial distribution of operator demographics 
- an issue that has largely been overlooked by RUI scholars. Producers at the RUI are highly diverse, but regional differences do exist. There is a rich tradition in rural studies documenting the extent to which gender, sex, culture, and ethnicity play a role in farmer decision-making and farm structure. This analysis provides initial data on operator demographics at the RUI; additional research is needed to explore the intersection between operators' social and cultural factors and farm persistence and growth at the RUI. The degree to which investments made in production and marketing systems at the RUI are successful is tempered by the extent to which we recognize and incorporate the unique history and technical assistance needs of different types of operators. The next generation of RUI policy and research should build on its historic focus of land use and markets to now include people.

\section{Acknowledgements}

The authors thank Dr. Jeff Sharp and Dr. Douglas Jackson-Smith for their support and encouragement. The authors thank the two anonymous reviewers and the journal editor for their extremely constructive and insightful comments.

\section{References}

American Farmland Trust [AFT]. (1997). Saving American farmland: What works. Madison, Wisconsin: The University of Wisconsin.

AFT. (2013). Threatened farmland: What's happening to our farmland? Retrieved March 2013 from http://www.farmland.org/resources/fote/ default.asp

American Horse Council. (2005). National economic impact of the U.S. horse industry. American Horse Council. Retrieved from http://www.horsecouncil.org/ national-economic-impact-us-horse-industry

Audirac, I. (1999). Unsettled views about the fringe: Rural-urban or urban-rural frontiers. In O. Furuseth and M. Lapping (Eds.), Contested Countryside: The Rural Urban Fringe in North America (pp. 7-32). Brookfield, VT: Ashgate Publishing.

Barbieri, C., \& Mahoney, E. (2009). Why is diversification an attractive farm adjustment strategy? Insights from Texas farmers and ranchers. Journal of Rural Studies, 25(1), 58-66. http://dx.doi.org/10.1016/j.jrurstud.2008.06.001

Berube, A., \& Forman, B. (2002). Living on the edge: Decentralization within cities in the 1990s [The Living Cities Census Series]. Washington, D.C.: Center on Urban \& Metropolitan Policy, The Brookings Institution. Retrieved from http://www.brookings.edu/research/reports/2002 /10/demographics

Bowler, I. (1999). Modelling farm diversification in regions using expert and decision support systems. Journal of Rural Studies, 15(3), 297-305. http://dx.doi.org/10.1016/S0743-0167(98)00064-3

Bryant, C. R., \& Johnston, T. R. R. (1992). Agriculture in the city's countryside. Toronto: University of Toronto Press.

Chiappe, M. B., \& Flora, C. B. (1998). Gendered elements of the alternative agriculture paradigm. Rural Sociology. 63(3), 372-393. http://dx.doi.org/ 10.1111/j.1549-0831.1998.tb00684.x

Clancy, K., \& Ruhf, K. (2010). Is local enough? Some arguments for regional food systems. Choices: The Magazine of Food, Farm \& Resource Issues, 25, 1. http://www.choicesmagazine.org/

Clark, J. K., McChesney, R., Munroe, D. K., \& Irwin, E. G. (2009). Spatial characteristics of exurban settlement pattern in the U.S. Landscape and Urban Planning, 90(3-4), 178-188. http://dx.doi.org/ 10.1016/j.landurbplan.2008.11.002

Colman, G., \& Elbert, S. (1984). Farming families: The farm needs everyone. Research in Rural Sociology and Development, 1, 61-78.

Esseks, D., Oberholtzer, L., Clancy, K., Lapping, M., \& Zurbrugg, A. (2009). Sustaining agriculture in urbanizing counties: Insights from 15 coordinated case studies [Final Report]. Lincoln, Nebraska: University of Nebraska Lincoln.

Feldman, S., \& Welsh, R. (1995). Feminist knowledge claims, local knowledge, and gender divisions of agricultural labor: Constructing a successor science. Rural Sociology, 60(1), 23-43. http://dx.doi.org/ 10.1111/j.1549-0831.1995.tb00561.x

Fennell, D. A., \& Weaver, D. B. (1997). Vacation farms and ecotourism in Saskatchewan, Canada. Journal of Rural Studies, 13(4), 467-475. http://dx.doi.org/10.1016/S0743-0167(97)00032-6

Fulton, W., Pendall, R., Nguyen, M., \& Harrison, A. (2001). Who sprawls most? How growth patterns differ across the U.S. Washington, D.C.: Center on Urban \& Metropolitan Policy, The Brookings Institution. 
Gasson, R. (1973). Goals and values of farmers. Journal of Agricultural Economics, 24(3), 521-542. http://dx.doi.org/10.1111/j.14779552.1973.tb00952.x

Gasson, R., \& Errington, A. (1993). The farm family business. Wallingford, Oxon, UK: CAB International.

Guthman, J. (2004). Agrarian dreams: The paradox of organic farming in California. Berkeley, California: University of California Press.

Hardesty, S. D. (2010). Do government policies grow local food? Choices: The Magazine of Food, Farm \& Resource Issues, 25, 1. http://www.choicesmagazine.org/

Hart, J. F. (1998). The rural landscape. Baltimore, Maryland: The Johns Hopkins University Press.

Heimlich, R. E. (1989). Metropolitan agriculture: Farming in the city's shadow. Journal of the American Planning Association, 55(4), 457-466. http://dx.doi.org/10.1080/01944368908975434

Heimlich, R. E., \& Anderson, W. D. (2001). Development at the urban fringe and beyond: Impacts on agriculture and rural land [Agricultural Economic Report No. AER803]. Washington, D.C.: USDA, Economic Research Service. http://www.ers.usda.gov/publications.aspx

Heimlich, R. E., \& Brooks, D. H. (1989). Metropolitan growth and agriculture: Farming in the city's shadow [Agricultural Economic Report No. AER619]. Washington, D.C.: USDA Economic Research Service. http://www.ers.usda.gov/publications.aspx

Hoppe, R. A., \& Korb, P. (2001, August). Farm operations facing development: Results from the Census Longitudinal File. Paper presented at the annual meeting of the American Agricultural Economics Association, Chicago, Illinois.

Imbruce, V. (2007). Bringing Southeast Asia to the Southeast United States: New forms of alternative agriculture in Homestead, Florida. Agriculture and Human V alues, 24(1), 41-59. http://dx.doi.org/10.1007/s10460-006-9034-0

Inwood, S., Clark, J. K., \& Bean, M. (2013). The differing values of multigeneration and firstgeneration farmers: Their influence on the structure of agriculture at the rural-urban interface. Rural Sociology, 78(3), 346-370. http://dx.doi.org/10.1111/ruso.12012
Inwood, S. M., \& Sharp, J. S. (2012). Farm persistence and adaptation at the rural-urban interface: Succession and farm adjustment. Rural Studies, 28(1), 107-117. http://dx.doi.org/10.1016/j.jrurstud.2011.07.005

Jackson-Smith, D. B., \& Jensen, E. (2009). The unimportance of dependence: Comparing indicators of farming dependence and agricultural importance. Rural Sociology, 74(1), 37-55. http://dx.doi.org/10.1526/003601109787524016

Jackson-Smith, D., \& Sharp, J. (2008). Farming in the urban shadow: Supporting agriculture at the ruralurban interface. Rural Realities, 12(4), 1-12.

Lev, L., \& Gwin, L. (2010). Filling in the gaps: Eight things to recognize about farm-direct marketing. Choices: The Magazine of Food, Farm \& Resource Issues, 25(1). http://www.choicesmagazine.org/magazine/ article.php?article $=110$

Levy, N. M. (1975). Native Hawaiian land rights. California Law Review, 63(4), 848-885. http://dx.doi.org/10.2307/3479836

Lobley, M., \& Potter, C. (2004). Agricultural change and restructuring: Recent evidence from a survey of agricultural households in England. Journal of Rural Studies, 20(4), 499-510. http://dx.doi.org/10.1016/j.jrurstud.2004.07.001

Lyson, T. A. (2004). Civic agriculture: Reconnecting farm, food and community. Medford, Massachusetts: Tufts University Press.

McNally, S. (2001). Farm diversification in England and Wales - What can we learn from the farm business survey? Journal of Rural Studies, 17(2), 247257. http://dx.doi.org/10.1016/S07430167(00)00050-4

Oberholtzer, L., Clancy, K., \& Esseks, J. D. (2010). The future of farming on the urban edge: Insights from fifteen U.S. counties about farmland protection and farm viability. Journal of Agriculture, Food Systems, and Community Development, 1(2), 59-75. http://dx.doi.org/10.5304/jafscd.2010.012.003

Parsons, B. (2011). Vermont's dairy sector: Is there a sustainable future for the $800 \mathrm{lb}$. gorilla? Food System Research Collaborative, Opportunities for Agriculture Working Paper Series, 1(4).

Sachs, S. (1996). Gendered fields: Rural women, agriculture and environment. Boulder, Colorado: Westview Press.

Salamon, S. (1992). Prairie patrimony: Family, farming, and community in the Midwest. Chapel Hill, North Carolina: University of North Carolina Press. 
Shucksmith, M., \& Herrmann, V. (2002). Future changes in British agriculture: Projecting divergent farm household behaviour. Journal of Agricultural Economics, 53(1), 37-50. http://dx.doi.org/10.1111/ j.1477-9552.2002.tb00004.x

Sparks, G. (2012). USDA directory records more than 7,800 farmers markets [Press release No. 0262.12]. Washington, D.C.: USDA Agricultural Marketing Service. Retrieved from http://www.usda.gov/ wps/portal/usda/usdamediafb? contentid $=2012 / 08$ 0262.xml\&printable $=$ true\&contentidonly $=$ true

Trauger, A. (2004). 'Because they can do the work': Women farmers and sustainable agriculture in Pennsylvania, USA. Gender, Place and Culture, 11,(2), 289-307. http://dx.doi.org/10.1080/0966369042000218491

Trauger, A., Sachs, C., Barbercheck, M., Kiernan, N. E., Brasier, K., \& Findeis, J. (2008).

Agricultural education: Gender identity and knowledge exchange. Journal of Rural Studies, 24(4), 432-439. http://dx.doi.org/10.1016/j.jrurstud.2008.03.007

U.S. Census Bureau. (2013). Distribution of Hispanic or Latino population by specific origin: 2010. Washington, D.C.: Author. Retrieved from http://www.census. gov/dataviz/visualizations/072/

U.S. Department of Agriculture, National Agricultural Statistics Service [USDA, NASS]. (2007a). 2007 Census of Agriculture: Demographics [Fact Sheet].
Washington, D.C.: Author. Retrieved from http://www.agcensus.usda.gov

USDA, NASS. (2007b). 2007 Census of Agriculture: Agricultural diversification [Fact sheet]. Washington, D.C.: Author. Retrieved from http://www.agcensus.usda.gov

USDA, NASS. (2008). 2007 Census of Agriculture: 2008 Organic Production Survey [Fact sheet]. Washington, D.C.: Author. http://www.agcensus. usda.gov/Publications/2007/Online Highlights/ Fact Sheets/Practices/organics.pdf

Wells, B. K., \& Gradwell, S. (2001). Gender and resource management: Community supported agriculture as caring-practice. Agriculture and Human Values, 18(1),107-119. http://dx.doi.org/10.1023/A:1007686617087

Whiting, K. A., McCall, C. A., \& Molnar, J. J. (2005, August). What equine-based activities, organizations, and facilities mean for rural development. Paper presented at the annual meeting of the Rural Sociological Society, Tampa, Florida.

Wolman, H., Galster, G., Hanson, R., Ratcliffe, M., Furdell, K., \& Sarzynski, A. (2005). The fundamental challenge in measuring sprawl: Which land should be considered? The Professional Geographer, 57(1), 94-105. http://dx.doi.org/ 10.1111/i.0033-0124.2005.00462.x 